\title{
ANALISIS KEUNTUNGAN USAHA TEMPE SEDAP "ANDIKA" DI KELURAHAN BAHU KECAMATAN MALALAYANG KOTA MANADO
}

\section{PROFIT ANALYSIS OF TEMPE "SEDAP" ANDIKA BUSINESS IN THE VILLAGE OF BAHU MALALAYANG SUB-DISTRICT MANADO CITY}

\author{
$\underline{\text { Olivia Claudia Pantas }}^{(1)}$, Lyndon Reindhard Jacob Pangemanan ${ }^{(2)}$, Rine Kaunang ${ }^{(2)}$ \\ 1) Mahasiswa Program Studi Agribisnis, Fakultas Pertanian, Universitas Sam Ratulangi, Manado \\ 2) Dosen Program Studi Agribisnis, Fakultas Pertanian, Universitas Sam Ratulangi, Manado \\ *Penulis untuk korespondensi: pantasoliviaclaudia@gmail.com
}

Naskah diterima melalui Website Jurnal Ilmiah agrisosioekonomi@unsrat.ac.id

Senin, 15 Februari 2021

Disetujui diterbitkan

Jumat, 28 Mei 2021

\begin{abstract}
The purpose of this study was to analyze the profits received by Tempe Sedap "ANDHIKA" home industry business in the village of Bahu, Malalayang Sub-District in one production process. This research was conducted for 3 months from October to December 2020. The research method used in this research is a case study. The data taken in this research is primary data using direct interview techniques with business owners using a list of questions that have been prepared in advance. The data collected in this study were then analyzed using profit analysis by calculating the difference between revenue and the costs used and then continued with the Revenue Cost Ratio (R / $C)$ Analysis formula. Based on the research results, it can be concluded that the Tempe Sedap "ANDHIKA" business in the Village of Bahu, Malalayang Sub-District, Manado City is very profitable and gets a value of $R / C=1.35$ which means this industry is profitable and feasible to be developed.
\end{abstract}

Keywords: profit analysis; home industry; tempe

ABSTRAK

Tujuan penelitian ini adalah menganalisis keuntungan yang diterima industri rumah tangga usaha tempe sedap "ANDHIKA" di Kelurahan Bahu Kecamatan Malalayang dalam satu kali proses produksi. Penelitian ini dilakukan selama 3 bulan dari bulan Oktober sampai bulan Desember 2020. Metode penelitian yang digunakan dalam penelitian ini adalah studi kasus. Data yang diambil dalam penelitian ini adalah data primer menggunakan teknik wawancara langsung dengan pemilik usaha menggunakan daftar pertanyaan yang telah dipersiapkan terlebih dahulu. Data yang dikumpulkan dalam penelitian ini kemudian dianalisis dengan menggunakan analisis keuntungan yaitu dengan menghitung selisih antara penerimaan dengan biaya yang digunakan dan kemudian di lanjutkan dengan rumus Analisis Revenue Cost Ratio (R/C). Berdasarkan hasil penelitian, dapat disimpulkan bahwa usaha tempe sedap "ANDHIKA" di Kelurahan Bahu, Kecamatan Malalayang, Kota Manado sangat menguntungkan dan mendapat nilai $\mathrm{R} / \mathrm{C}=1,35$ yang berarti industri ini menguntungkan dan layak untuk dikembangkan.

Kata Kunci: analisis keuntungan; industri rumah tangga; tempe 


\section{PENDAHULUAN}

\section{Latar Belakang}

Sektor industri pengolahan merupakan salah satu penyumbang dalam memantapkan perekonomian di Indonesia. Industri pengolahan pangan merupakan industri yang bergerak dalam pengolahan hasil pertanian, baik nabati maupun hewani menjadi produk pangan olahan, yang dapat dibuat dan dikembangkan dari sumber daya alam lokal (Soleh dalam Sarfan, 2016).

Kedelai merupakan komoditas terpenting ketiga setelah padi dan jagung di Indonesia. Lebih dari 90 persen kedelai Indonesia digunakan sebagai bahan pangan, terutama pangan olahan, yaitu sekitar 88 persen untuk tahu dan tempe, 10 persen untuk pangan olahan lainnya dan sekitar 2 persen untuk benih (Sudaryanto dan Swastika, 2007). Salah satu hasil olahan yang menggunakan kedelai sebagai bahan baku adalah tempe. Tempe diminati oleh masyarakat, selain harganya murah, juga memiliki kandungan protein nabati yang tinggi. Usaha pengolahan tempe yang sebagian besar berskala industri rumah tangga banyak di geluti oleh masyarakat Indonesia di berbagai daerah.

Tempe Sedap "ANDHIKA” merupakan salah satu industri rumah tangga yang menggunakan kedelai sebagai bahan baku pembuatan tempe. Usaha Tempe Sedap "ANDHIKA" terletak di Kelurahan Bahu, Kecamatan Malalayang, Kota Manado. Usaha rumah tangga Tempe Sedap "ANDHIKA" telah berjalan selama kurang lebih 16 tahun dan sampai saat ini masih bertahan dan memberikan keuntungan kepada pengusaha selain untuk kebutuhan konsumsi keluarga tetapi juga untuk kontinuitas usaha tempe. Usaha ini relatif stabil karena banyaknya tempe yang diproduksi setiap hari relatif sama setiap satu kali proses produksi namun hasil produksi yang dijual sebagian besar dijual pada pelanggan tetap sehingga jangkauan pasar untuk usaha ini masih kurang besar. Usaha yang telah beroperasi selama enam belas tahun ini sudah memiliki izin usaha serta label sehingga produk tempe yang dihasilkan telah dipasarkan di supermarket.

\section{Kedelai}

Kedelai merupakan salah satu jenis kacang-kacangan yang mengandung protein nabati yang tinggi, sumber lemak, vitamin, dan mineral. Apabila cukup tersedia di dalam negeri akan mampu memperbaiki gizi masyarakat melalui konsumsi kedelai segar maupun melalui konsumsi kedelai olahan seperti tahu, tempe, tauco, kecap, susu dan lain sebagainya (Crowder, 2007). Kedelai mempunyai kegunaan yang luas dalam tatanan kehidupan manusia. Penanaman kedelai dapat meningkatkan kesuburan tanah, karena akarakarnya dapat mengikat Nitrogen dari udara dengan bantuan bakteri Rhizobium sp, sehingga unsur nitrogen bagi tanaman tersedia dalam tanah. Limbah tanaman kedelai berupa brangkasa dapat dijadikan bahan pupuk organik penyubur tanah. Limbah dari bekas proses pengolahan kedelai, misalnya ampas tempe, ampas kecap dan lain-lain, dapat dimanfaatkan untuk bahan makanan tambahan (konsentrat) pada pakan ternak (Rukmana, 2006).

\section{Fermentasi Tempe}

Fermentasi adalah proses produksi energi dalam sel dalam keadaan anaerobik (tanpa oksigen). Proses fermentasi menjadikan tekstur kedelai menjadi lebih lunak sehingga lebih mudah dicerna. Pengolahan kedelai menjadi tempe juga menurunkan kadar stakiosa dan raffinosa, senyawa yang dapat menyebabkan kembung perut atau flatulensi. Tempe yang baik ialah yang tidak banyak campuran-campurannya, misalkan ampas kedelai, onggok, dan sebagainya. Selain itu, tempe yang baik dibuat dari kacang kedelai yang tidak busuk dan tidak banyak batubatu kecilnya, dan dipilih biji kedelai yang tua serta berkilat dan agak berminyak (Astawan, 2008).

\section{Konsep Agroindustri}

Agroindustri berasal dari dua kata, yaitu agricultural dan industry yang berarti suatu industri yang menggunakan hasil komuditi pertanian sebagai bahan baku utamanya. Definisi agroindustri dapat dijabarkan sebagai kegiatan industri yang memanfaatkan hasil pertanian sebagai bahan baku yang dapat diolah menjadi produk yang mempunyai nilai tambah serta mempunyai manfaat lebih dari hasil komuditi 
pertanian lainnya. agroindustri meliputi industri pengolahan hasil pertanian, industri yang memproduksi peralatan dan mesin pertanian, industri input pertanian (pupuk, pestisida, dan lain-lain) dan industri jasa sektor pertanian. Apabila dilihat dari sistem agribisnis, agroindustri merupakan bagian (subsistem) agribisnis yang memproses dan mentranformasikan bahan-bahan hasil pertanian (bahan makanan, kayu dan serat) menjadi barang-barang setengah jadi yang langsung dapat dikonsumsi dan barang atau bahan hasil produksi industri yang digunakan dalam proses produksi seperti traktor, pupuk, pestisida, mesin pertanian dan lain-lain.

Dari batasan diatas, agroindustri merupakan subsektor yang luas yang meliputi industri hulu sektor pertanian sampai dengan industri hilir. Industri hulu adalah industri yang memproduksi alat-alat dan mesin pertanian serta industri sarana produksi yang digunakan dalam proses budidaya pertanian. Sedangkan industri hilir merupakan industri yang mengolah hasil pertanian menjadi bahan baku atau barang yang siap dikonsumsi atau merupakan industri pasca panen dan pengolahan hasil pertanian. Dalam kerangka pembangunan pertanian, agroindustry merupakan penggerak utama perkembangan sektor pertanian, terlebih dalam masa yang akan datang posisi pertanian merupakan sektor andalan dalam pembangunan nasional sehingga peranan agroindustri akan semakin besar. Dengan kata lain, dalam upaya mewujudkan sektor pertanian yang tangguh, maju dan efisien sehingga mampu menjadi leading sektor dalam pembangunan nasional, harus ditunjang melalui pengembangan agroindustri, menuju agroindustri yang tangguh, maju serta efisien.

\section{Jenis Industri}

Industri adalah kelompok aktivitas ekonomi yang sangat berkaitan erat, yang diklasifikasikan sesuai dengan jenis dari barang dan jasa yang disediakan, sedangkan industri pengolahan adalah suatu kegiatan ekonomi yang melakukan kegiatan mengubah suatu barang dasar secara mekanis, kimia, atau dengan tangan sehingga menjadi barang jadi/setengah jadi, dan atau barang yang kurang nilainya menjadi barang yang lebih tinggi nilainya dan sifatnya lebih dekat kepada pemakai akhir. Menurut Soekartawi (2001) maka industri dapat digolongkan menjadi empat kategori, yaitu:

1. Industri Besar (Large Scale manufacturing Industries) Mempunyai pekerja berkisar 100 orang

2. Industri Sedang (Medium Scale manufacturing Industries) Mempunyai pekerja berkisar 20-99 orang

3. Industri Kecil (Small Scale manufacturing Industries) Mempunyai pekerja berkisar 519 orang

4. Industri Rumah Tangga (Household and Cottage Industries) Mempunyai pekerja berkisar 1-4 orang

\section{Konsep Biaya}

Biaya adalah harga pokok yang telah memberi manfaat dan telah habis dimanfaatkan. Biaya dapat diartikan sebagai pengorbanan sumber ekonomi baik yang terwujud maupun tidak terwujud yang dapat ditukar dalam satuan uang, yang telah terjadi atau akan terjadi untuk mencapai tujuan tertentu. Biaya merupakan salah satu faktor penting dalam penentuan harga pokok produksi dan harga jual produksi. Menurut Supriyono (2000) Biaya adalah harga perolehan yang digunakan dalam memperoleh penghasilan atau revenue yang akan dipakai sebagai pengurangan penghasilan.

\section{Konsep Produksi}

Produksi sering diartikan sebagai penciptaan guna, dimana kemampuan barang atau jasa untuk memenuhi kebutuhan manusia. Produksi meliputi semua aktifitas dan tidak hanya mencakup pembuatan barang-barang yang dapat dilihat. Produksi adalah suatu kegiatan untuk meningkatkan manfaat dengan cara mengkobinasikan faktor-faktor produksi capital, tenaga kerja, teknologi. Produksi merupakan usaha meningkatkan manfaat dengan cara mengubah bentuk, memindahkan tempat, dan menyimpan (Santoso, 2009). Produksi sering didefinisikan sebagai pencipta guna, dimana guna berarti kemampuan barang atau jasa untuk memenuhi kebutuhan manusia. faktor produksi adalah benda-benda yang 
disediakan oleh alam atau diciptakan oleh manusia yang dapat digunakan untuk memproduksi barang dan jasa. Produksi pertanian yang optimal adalah yang mendatangkan produk yang menguntungkan. Ditinjau dari sudut ekonomi ini berarti biaya faktor-faktor yang berpengaruh pada produksi jauh lebih kecil bila dibandingkan dengan hasil yang diperoleh sehingga petani dapat memperoleh keuntungan dari usaha lainnya (Henry, 2013).

Biaya produksi adalah nilai dari semua faktor produksi yang digunakan, baik dalam bentuk benda maupun jasa selama proses produksi berlangsung. Adanya unsur-unsur produksi yang bersifat tetap dan tidak tetap dalam jangka pendek mengakibatkan munculnya dua kategori biaya, yaitu biaya tetap dan biaya variabel (Khazanani, 2011). Menurut Mulyadi (2009) Biaya dapat dibagi berdasarkan sifatnya, artinya mengkaitkan antara pengeluaran yang harus di bayar dengan produk atau output yang dihasilkan yaitu:

a. Biaya Tetap (Fixed Cost) adalah biaya yang besarnya tidak tergantung pada jumlah produksi.

b. Biaya Variabel (Variabel Cost) adalah biaya yang besarnya, tergantung pada tingkat produksi.

c. Biaya Total (Total Cost) merupakan penjumlahan dari biaya tetap dan biaya variabel dalam proses produksi.

\section{Konsep Harga}

Harga adalah variabel yang dapat dikendalikan dan dapat menentukan diterima tidaknya suatu produk sangat oleh kons umen. Murah atau mahalnya harga suatu produk sangat relatif sifatnya (Anoraga, 2002). Harga yang ditetapkan harus dapat menutup semua biaya yang telah dikeluarkan, jika harga ditetapkan terlalu tinggi maka kurang menguntungkan karena pembeli dan volume penjualan berkurang. Harga jual adalah sejumlah biaya yang dikeluarkan perusahaan untuk memproduksi suatu barang atau jasa ditambah dengan presentase laba yang diinginkan pedagang. Untuk mencapai laba yang diinginkan oleh pedagang, maka pedagang akan melakukan daya tarik konsumen dengan cara menentukan harga yang tepat untuk produk yang terjual.

\section{Penerimaan (Revenue)}

Penerimaan adalah jumlah nilai atau hasil penjualan yang diterima dalam menjalankan usaha. Total penerimaan dalam usahatani diperoleh dari produksi fisik dikalikan dengan harga produksi. Bila keadaan memungkinkan, maka sebaiknya petani mengolah sendiri hasil pertaniannya untuk mendapatkan kualitas hasil yang baik harganya relatif tinggi dan akhirnya juga akan mendatangkan total penerimaan yang lebih besar (Soekartawi, 2006).

\section{Keuntungan}

Keuntungan adalah selisih antara penerimaan total dan biaya-biaya (cost). Biaya ini dalam banyak kenyataan, dapat diklasifikasikan menjadi dua yaitu biaya tetap seperti sewa tanah, pembelian alat pertanian dan biaya tidak tetap seperti biaya yang dikeluarkan untuk membeli bibit, pupuk, obat-obatan, pembayaran tenaga kerja. Keuntungan merupakan kegiatan pedagang yang mengurangkan beberapa biaya yang dikeluarkan dengan hasil penjualan yang diperoleh. Apabila hasil penjualan yang diperoleh dikurangi dengan biaya-biaya tersebut nilainya positif maka diperoleh keuntungan (laba). Uang diterima dan dikurangi dengan biaya variabel, maka sisanya disebut keuntungan.

\section{Konsep Analisis Revenue Cost (R/C)}

Menurut Soekartawi, Untuk mengetahui apakah usaha yang dilaksanakan mengalami keuntungan atau kerugian, maka diperlukan analisis $\mathrm{R} / \mathrm{C}$ yang merupakan perbandingan antara penerimaan dan biaya.

$$
\mathrm{a}=\mathrm{R} / \mathrm{C}
$$

Dimana :

$\mathrm{a}=$ Perbandingan antara penerimaan dan biaya

$\mathrm{R}=$ Revenue

$\mathrm{C}=$ Cost (Biaya)

Apabila :

$\mathrm{R} / \mathrm{C}<1$

Berarti Usaha Tempe mengalami kerugian

$\mathrm{R} / \mathrm{C}=1$

Berarti Usaha Tempe tidak menguntungkan dan tidak merugikan

$\mathrm{R} / \mathrm{C}>1$

Berarti Usaha Gorengan menerima keuntungan. 


\section{Rumusan Masalah}

Berdasarkan latar belakang yang telah diuraikan di atas, maka yang menjadi rumusan masalah dalam penelitian ini adalah berapa besar keuntungan yang diperoleh industri usaha Tempe dalam satu kali proses produksi di Kelurahan Bahu Kecamatan Malalayang Kota Manado.

\section{Tujuan Penelitian}

Tujuan dari penelitian ini adalah menganalisis berapa keuntungan yang diterima industri Usaha Tempe Sedap "ANDIKA" di Kelurahan Bahu Kecamatan Malalayang Kota Manado dalam satu kali proses produksi.

\section{Manfaat Penelitian}

Manfaat dari penelitian ini adalah agar dapat memberikan informasi bagi pihak-pihak yang memerlukannya untuk menambah wawasan dan pengetahuan yang lebih luas mengenai usaha Tempe. serta diharapkan dapat digunakan sebagai bahan kajian untuk peningkatan usaha dalam rangka mencapai keuntungan yang maksimal.

\section{METODE PENELITIAN}

\section{Waktu dan Tempat Penelitian}

Penelitian ini dilakukan selama 3 bulan yaitu sejak bulan Oktober Desember tahun 2020 dengan lokasi penelitian dilaksanakan di Kelurahan Bahu Kecamatan Malalayang Kota Manado.

\section{Metode Pengumpulan Data}

Metode penelitian yang digunakan dalam penelitian ini adalah studi kasus pada usaha Tempe Sedap "ANDHIKA" di Kelurahan Bahu Kecamatan Malalayang Kota Manado. Data yang di ambil adalah data primer menggunakan teknik wawancara langsung dengan pemilik usaha. menggunakan daftar pertanyaan yang telah dipersiapkan terlebih dahulu.

\section{Konsep Pengukuran Variabel}

Variabel-variabel yang diukur dalam penelitian ini adalah:

1. Produksi : Yaitu, jumlah produksi Tempe yang dihasilkan dalam satu kali produksi dihitung dalam satuan perbungkus.

2. Harga : Harga jual dari produksi Tempe yang dihasilkan dihitung dalam satuan rupiah per bungus (Rp/bungkus).

3. Biaya Produksi (Rp) Yaitu, besarnya biaya yang dikeluarkan dalam pembuatan Tempe setiap kali produksi yang terdiri dari biaya tetap, biaya variabel, dan biaya tambahan

\section{Metode Analisis Data}

Data yang dikumpulkan dalam penelitian ini kemudian dianalisis dengan menggunakan analisis keuntungan yaitu dengan menghitung selisih antara penerimaan dengan biaya yang digunakan. Data yang dikumpulkan akan disajikan dalam bentuk variabel dan dianalisis secara deskriptif. Dan kemudian di lanjutkan dengan rumus Analisis Revenue Cost Ratio (R/C).

\section{HASIL DAN PEMBAHASAN}

\section{Deskripsi Umum Usaha Tempe Sedap "ANDHIKA"}

Usaha tempe ini berdiri sejak tahun 1996 yang dikelola oleh orangtua Bapak Alfrets Warouw dan pada akhir tahun 2004 diteruskan oleh Ibu Yessy Paendong. Rumah yang digunakan untuk proses produksi adalah rumah sendiri di Jalan Pulau Sulawesi, Lingkungan VI, Kelurahan Bahu Kecamatan Malalayang Kota Manado. Proses produksi Tempe Sedap "ANDHIKA" semuanya dilakukan dengan bantuan mesin. Usaha ini berproduksi setiap hari dengan jam operasional selama \pm 8 jam per hari. Proses produksi dimulai dari jam 06.00 sampai 14.00, belum termasuk dengan proses perebusan bahan baku kedelai.

Hasil keuntungan dari usaha tempe diakui pemilik mampu untuk memenuhi kebutuhan pangan (konsumsi sehari-hari) keluarga, membiayai sekolah anak serta cucu, modal untuk kesinambungan usaha serta hasil yang didapatkan ditabung untuk kebutuhan keluarga kedepan. Tempe Sedap "ANDHIKA" pada tahun 2006 telah mendapat izin usaha, dimana perpanjangan dilakukan setiap lima tahun. 


\section{Produksi, Harga, dan Biaya Produksi}

1. Produksi

Pada dasarnya setiap industri dalam meningkatkan produksinya bertujuan untuk meningkatkan keuntungan yang diterimanya. Hasil produksi yang diperoleh dinilai dari biaya yang dikeluarkan dan penerimaan yang diperoleh. Dalam hasil Tempe. Dalam penelitian ini produk Usaha Tempe Sedap "Andhika" yang untuk dijual sebanyak 600 Bungkus dalam satu kali produksi.

2. Harga Jual

Harga merupakan persetujuan antara pembeli dengan penjual dalam penjual satu buah tertentu. Untuk harga / (satu bungkus) Tempe yaitu Rp. 3.000.

3. Biaya Produksi

Biaya produksi merupakan keseluruhan biaya yang digunakan untuk membiayai keseluruhan proses usaha tersebut. Biaya produksi untuk mengelolah Tempe terdiri dari biaya variabel (Variable Cost) dan biaya tetap (Fixed Cost). Dalam penelitian ini menunjukan bahwa dalam produksi usaha Tempe mengeluarkan beberapa biaya untuk menunjang kegiatan produksi yaitu biaya tetap, berupa biaya penyusutan alat, dan biaya variabel.

\section{Biaya Tetap Pada Usaha Tempe Sedap "Andhika"}

Biaya tetap (FC) yang dimaksud dalam penelitian ini adalah biaya yang tidak habis dalam satu kali proses produksi, tetapi hanya mengalami penyusutan atau yang disebut sebagai biaya investasi seperti pengadaan peralatan. Penyusutan dihitung menggunakan metode garis lurus yaitu nilai awal dari peralatan dikurangi dengan nilai sisa kemudian dibagi dengan umur ekonomis dari peralatan tersebut. Nilai awal diperoleh dari biaya yang digunakan untuk membeli peralatan tersebut sedangkan umur ekonomis dilihat dari lamanya penggunaan peralatan tersebut masih menguntungkan.

Penyusutan alat merupakan biaya yang perlu dimasukan kedalam perhitungan biaya tetap. Biaya penyusutan alat yaitu pengurangan nilai yang disebabkan oleh pemakaian alat selama proses berlangsung. Penyusutan yang dihitung adalah umur teknis alat berdasarkan pemakaian alat-alat produksi milik sendiri.
Tabel 1. Nilai Penyusutan Alat Pada Usaha Tempe Sedap

\begin{tabular}{lc}
\multicolumn{1}{c}{ "Andhika" } \\
\hline \multicolumn{1}{c}{ Jenis Produk } & Penyusutan Alat \\
\hline Wajan & 95,03 \\
Mesin Dynamo Motor & 226,88 \\
Mesin Giling & 265,41 \\
Panci & 51,20 \\
Kompor Besar & 66,78 \\
Rak Tempe Besi & 336,04 \\
\hline Total & $\mathbf{1 0 4 . 1 3 4}$ \\
\hline
\end{tabular}

Dalam penelitian ini komponen nilai penyusutan wajan yaitu sebesar Rp.95,03/hari. Wajan yang digunakan adalah wajan besar dengan ukuran $75 \mathrm{~cm}$ dan tinggi $25 \mathrm{~cm}$ dipakai untuk menggoreng, dan harga wajan sebesar Rp.560.000, dan untuk harga ekonomisnya sebesar Rp.5.000, dan Mesin dynamo motor sebesar Rp.226,88/hari, dengan harga mesin dynamo motor sebesar Rp.1.400.000, dan untuk harga ekonomisnya sebesar Rp.75.000, dan Mesin giling sebesar Rp.265,41/hari, dengan harga Mesin giling sebesar Rp.1.600.000, dan untuk harga ekonomisnya sebesar Rp.50.000, dan Panci sebesar Rp.51,20/hari, dengan harga panci sebesar Rp.300.000, dan untuk harga ekonomisnya sebesar Rp.1.000, dan Kompor rinaai tekanan gas yang rendah, tetapi menghasilkan api yang besar, nilai penyusutan alat yaitu 66,78/hari. Harga kompor sebesar Rp.400.000, dan untuk harga ekonomisnya sebesar Rp.10.000, dan Rak tempe sebesar Rp.336,04/hari, dengan harga rak tempe sebesar Rp.2.000.000, dan untuk harga ekonomisnya sebesar Rp.37.500.

\section{Biaya Variabel Pada Usaha Tempe Sedap "Andhika"}

Biaya variabel adalah yang digunakan dalam satu kali proses produksi dan besar kecilnya biaya dipengaruhi oleh produksi yang diperoleh. dalam biaya variabel ini yang dihitung adalah biaya bahan baku, biaya tambahan/penolong seperti gas elpiji $3 \mathrm{~kg}$, tepung beras putih, ragi tempe dan plastik.

Tabel 2. Biaya Variabel pada Usaha Tempe Sedap "Andhika"

\begin{tabular}{lc}
\hline \multicolumn{1}{c}{ Biaya-Biaya Produksi } & Rata-Rata Biaya (Rp) \\
\hline Biaya Bahan Baku & 400.000 \\
Biaya Tenaga Kerja & 30.000 \\
Biaya Transportasi & 10.000 \\
Biaya Tambahan/Penolong & \\
a. Gas Elpiji 3 kg & 9.000 \\
b. Tepung Beras Putih & 8.000 \\
c. Ragi Tempe & 1.200 \\
d. Plastik & 4.000 \\
\hline Total Biaya Variabel & $\mathbf{4 6 2 . 2 0 0}$
\end{tabular}




\section{Biaya Bahan Baku}

Biaya bahan baku dalam proses pembuatan Tempe ini merupakan salah satu komponen biaya produksi yang diperhitungkan, biaya bahan baku dalam pembuatan Tempe ini yaitu kedelai dan ragi.

\section{Penerimaan}

Penerimaan adalah jumlah produksi dikalikan dengan harga jual yang berlaku. Dalam kegiatan usaha ini selalu meningkatkan produksi dengan harapan bahwa pendapatan yang diterima akan naik sejalan dengan bertambahnya produksi yang dihasilkan. Penerimaan berkaitan erat dengan volume produksi dan harga jual, oleh karena itu penerimaan merupakan hasil perkalian antara harga jual yang berlaku dalam produksi. Dalam penelitian ini harga Tempe Rp3.000/bungkus, jadi hasil Tempe yang diproduksi 600 bungkus adalah sebesar Rp.1.800.000, Total produksi Tempe adalah sebesar Rp.1.800.000

\section{Keuntungan}

Keuntungan yang diperoleh sangat tergantung dari jumlah penerimaan yang diterima dikurangi dengan biaya yang dikeluarkan, besarnya penerimaan yang didapat merupakan hasil perkalian antara harga jual produk dengan jumlah produksi yang dihasilkan sehingga tinggi produksi dengan biaya semakin kecil dan harga akan mempengaruhi keuntungan.

Tabel 3. Keuntungan Usaha Tempe Sedap

\begin{tabular}{lr}
\multicolumn{2}{c}{ "Andika" } \\
\hline \multicolumn{1}{c}{ Uraian } & Jumlah \\
\hline Penerimaan & 1.800 .000 \\
Total Biaya & 462.200 \\
\hline Keuntungan & $\mathbf{1 . 3 3 7 . 8 0 0}$ \\
\hline
\end{tabular}

Dalam penelitian ini dapat dilihat bahwa Total Penerimaan, Total Biaya dan Total Keuntungan dari Tempe. Dengan Penerimaan sebesar Rp. 1.800.000, Besar Biaya Rp. 462.200, dan Keuntungan yang di dapat dalam usaha Tempe dalam satu kali proses produksi adalah sebesar Rp. 1.337.800.

\section{Revenue Cost Ratio}

Tingkat keuntungan ekonomi dapat diketahui dengan menggunakan Analisis Revenue Cost Ratio (R/C ratio) adalah perbandingan antara penerimaan dan biaya, ratio yang menjadi parameternya adalah nilai $\mathrm{R} / \mathrm{C}=1$ berarti usaha tidak untung dan tidak rugi, nilai $\mathrm{R} / \mathrm{C}<1$ berarti usaha rugi, nilai $\mathrm{R} / \mathrm{C}$ $>1$ berarti usaha untung. Nilai R/C Usaha Industri Usaha Tempe diKelurahan Bahu Kecamatan Malalayang dapat dilihat bahwa nilai rata rata $\mathrm{R} / \mathrm{C}$ dari produksi gorengan ini menunjukan angka $>1$. Nilai $\mathrm{R} / \mathrm{C}$ dari usaha Tempe ini adalah 3.89 maka usaha Tempe ini menguntungkan.

\section{KESIMPULAN DAN SARAN}

\section{Kesimpulan}

Dari penelitian ini dapat disimpulkan bahwa Usaha Tempe Sedap "ANDIKA" di Kelurahan Bahu Kecamatan Malalayang Kota Manado ini menguntungkan. Usaha Industri Tempe ini mengeluarkan total rata-rata biaya dalam sekali produksi adalah sebesar Rp. 492.200, total rata-rata penerimaan adalah sebesar Rp. 1.800.000, dan mendapatkan total rata- rata keuntungan adalah sebesar $\mathrm{Rp}$. 1.337.800 dalam sekali produksi. dan menggunakan R/C Ratio menjadi 1.35 yang berarti industri ini menguntungkan.

\section{Saran}

Penulis menyarankan pengembangan industri ini perlu meningkatkan produk sehingga konsumen lebih tertarik dengan tempe ini, dan proses pembuatan tempe harus lebih diefektifkan agar bisa mendapatkan keuntungan yang maksimal, dan juga usaha ini perlu meningkatkan skill pekerja sehingga proses produksi bisa berjalan lancar dan industri ini juga perlu diperhatikan oleh pemerintah agar usaha ini dikenal lebih luas dan boleh berjalan dengan lancar. 


\section{DAFTAR PUSTAKA}

Anoraga, P. \& J. Sudantoko. 2002. "Koperasi Kewirausahaan dan Usaha Kecil. Rineka Cipta". Jakarta.

Astawan, M. 2008. Sehat Dengan Tempe. Panduan Lengkap Menjaga Kesehatan dengan Tempe. Jakarta. PT Dian Rakyat.

Crowder, 2007. Genetika Tumbuhan. Yogyakarta. Gadjah Mada University Press.

Henry, S. 2013. "Pengantar Ilmu Ekonomi". CAPS. Yogyakarta.

Rukmana, R. dan Yuyun Yuniarsih., 2006. Kedelai Budidaya dan Pascapanen. Yogyakarta. Kanisius.

Santoso, W., Utami, P. dan Dumasari. 2009. "Analisis Pendapatan dan Biaya Produksi Agroindustri Tahu di Desa Pandansari kecamatan Ajibarang Kabupaten Banyumas". Jurnal. Fakultas Pertanian. Universitas Muhammadiayah Purworkerto.
Sarfan. 2016. Analisis Keuntungan dan Kelayakan Usaha Pembuatan Tahu di Kelurahan Liabuku Kecamatan Bungi Kota Bau-Bau (Studi Kasus Pada Industri Tahu Mekar). Skripsi. Universitas Halu Oleo.

Soekartawi. 2001. "Pengantar Agroindustri". Jakarta.

Sudaryanto dan Swastika. 2007. Ekonomi Kedelai di Indonesia. http:// balitkabi. litbang. pertanian.go.id /wpcontent/ uploads/ 2016/ 03/ dele_1. tahlim-1.pdf (diakses 6 Desember 2020).

Supriyono, R.A, 2000. "Akutansi Biaya". Perencanaan dan Pengendalian Biaya serta pembuatan keputusan, Edisi kedua, BPFE, Yogyakarta. 